\title{
Inflammatory and Angiogenic Abnormalities in Diabetic Wound Healing: Role of Neuropeptides and Therapeutic Perspectives
}

\author{
Ana Tellechea ${ }^{\#, 1}$, Ermelindo Leal ${ }^{\#, 1}$, Aristidis Veves² and Eugénia Carvalho*,1 \\ ${ }^{1}$ Center for Neurosciences and Cell Biology, University of Coimbra, Portugal; ${ }^{2}$ Microcirculation Lab and Joslin-Beth \\ Israel Deaconess Foot Center, Harvard Medical School, Boston, MA, USA
}

\begin{abstract}
Diabetic foot ulceration (DFU) is one of the most costly and debilitating complications of diabetes and is the leading cause of non-traumatic amputations, affecting $15 \%$ of the diabetic population. Impaired wound healing in diabetic patients without large-vessel disease has been attributed to microvascular dysfunction, neuropathy, and abnormal cellular and inflammatory responses. These abnormalities have been examined mainly in animal models although a few studies have been undertaken in diabetic patients. This review provides an overview of the inflammatory and vascular abnormalities in DFU and emphasises the role of angiogenic growth factors, endothelial progenitor cells (EPCs), and neuropeptides as mediators of wound healing and potential therapeutic agents for these chronic, non-healing ulcers.
\end{abstract}

Keywords: Wound healing, inflammation, angiogenesis, neuropeptides.

\section{INTRODUCTION}

Diabetes mellitus (DM) is a serious problem of public health worldwide and it tends to increase in numbers, mainly in the developed countries. In the USA, recent data refer that $8 \%$ of the general population and $25 \%$ of the population over the age of 65 is diabetic [1]. One of the most serious and debilitating complications of diabetes is the development of chronic non-healing foot ulcerations. Diabetic foot ulceration (DFU) is estimated to occur in 15\% of diabetic patients, often requires prolonged hospitalizations for its management and is the major cause of disease-associated amputations in the western world [1-3].

Wound healing is an innate host response for restoration of tissue integrity. It is a complex process encompassing a number of coordinated steps, including homeostasis/coagulation, inflammation, migration-proliferation and remodeling [4]. After a skin break is produced, leakage of blood from blood vessels occurs and a fibrin clot is formed, plugging the defect. This provides an immediate, provisional repair and initiates a cascade of events that culminate to wound closure. In this process, the aggregated platelets release cytokines and growth factors that recruit neutrophils and monocytes. Fibroblasts, epithelial cells and endothelial cells (EC) also migrate to the wound site to form a contractile granulation tissue that brings the wound margins closer. Meanwhile, a fresh surface epithelium covers the wound surface and the granulation tissue differentiates progressively approaching the structural and functional characteristics of the mature dermis, finally repairing the lost tissue. This cascade implies the orderly initiation and arrest of many

*Address correspondence to this author at the Center for Neurosciences and Cell Biology, University of Coimbra, 3000-517 Coimbra - Portugal;

Tel: +351-96-505-8798; Email: ecarvalh@cnc.uc.pt

"Both authors have contributed equally to this work complex biological phenomena including cell proliferation, cell migration, cell differentiation and extracellular matrix (ECM) deposition [5]. The coordinated actions of cell and matrix signals orchestrate these processes.

The pathophysiologic relationship between diabetes and impaired healing is complex. In contrast to acute wounds that progress through the phases of wound healing linearly in healthy individuals, chronic wounds in diabetic patients become stalled in different phases and progression does not occur in synchrony due to diabetes associated neuropathy, microangiopathy and impaired immune function $[4,6]$.

Studies in transgenic animal models null for specific genes coding for molecules known to play a role in wound healing, as well as wound healing research in embryos and the emerging cell-based strategies, have shown to be useful in the understanding of wound healing mechanisms.

However, further investigation is needed in order to: i) identify the precise molecular signals that regulate cell activity in a particular phase, ii) modulate cells/matrix molecules to stimulate wound healing, and iii) clarify the mechanisms of wound healing failure in chronic skin wounds.

This review focuses on the inflammatory and vascular abnormalities in DFU and emphasises the role of neuropeptides, angiogenic growth factors and EPCs as potential therapeutic agents for these chronic, non-healing ulcers.

\section{CAUSES OF DIABETIC FOOT ULCERATION}

Both acute and long-term occurrence of type 1 and type 2 Diabetes mellitus can result in complications of the neuronal and vascular systems. Since DM affects small and large blood vessel, it is known to cause various micro and macrovascular complications. The incidence of microvascular complications, specifically, nephropathy, retinopathy and peripheral neuropathy increases with the duration of diabetes. Diabetes-associated macrovascular diseases, namely, coronary artery disease, cerebrovascular disease and periph- 
eral vascular disease occur mainly as a result of accelerated atherosclerosis. Peripheral vascular disease (PVD) and peripheral neuropathy $(\mathrm{PN})$ are the leading causes of DFU.

Peripheral vascular disease is a broad term that includes any disorder of the peripheral circulatory system, although it is often used as a synonym for peripheral arterial disease (PAD). According to different studies, the prevalence of PAD in patients with DFU varies from $10 \%$ to $60 \%$ [7-10]. In fact, a recent Eurodiale study, which was conducted in 14 European centers, has shown that the presence of PAD is a strong predictor of chronic, nonhealing foot ulcers [11]. In a previous study, Jude and colleagues [12] reported that the severity of PAD can be associated with higher rates of lower extremity amputation, morbidity and mortality.

Peripheral neuropathy is characterized by a progressive loss of nerve fibers that will eventually lead to loss of pain perception. It is now well established that $\mathrm{PN}$ is a key factor in the development of DFU. Also, PN is reported in 30 to $50 \%$ of diabetic patients. The risk factors for diabetic neuropathy include hyperglycemia, hyperlipidemia, high blood pressure, obesity, age over 40, and long-term occurrence of DM $[13,14]$.

It is estimated that peripheral neuropathy increases the risk of DFU by 8- to 18- fold and the risk of lower extremity amputation by 2- to 15 - fold. The mechanisms through which PN triggers the pathogenic pathway for ulceration are complex. The reduction of protective sensitivity, including sensitivity to pain and heat, leads to a diminished perception of pain stimuli. In addition, $\mathrm{PN}$ affects the motor system causing a progressive weakening of the intrinsic muscle components. Furthermore, the autonomous component of neuropathy leads to anhydrosis resulting in dry skin with lowered barrier function, and increases the arterio-venous shunting, leading to altered skin and bone perfusion.

\section{INFLAMMATION IN WOUND HEALING}

Skin injury causes the immediate onset of acute inflammation. The inflammatory response is mostly coordinated by two principal effectors derived from the circulation: polymorphonuclear neutrophils (PMNs) and monocyte-derived macrophages.

Neutrophils appear earlier and in a larger amount in the wounded area than monocytes, partly due to their greater count in circulation. Therefore, the initial inflammatory phase is characterized by a massive infiltration of PMNs. Later in inflammation, the number of PMNs declines and macrophages predominate.

PMNs and monocytes from dermal blood vessels are attracted to the site of injury by chemotatic signals, including complement factor 5a, fibrin by-products, platelet derived growth factor (PDGF), transforming growth factor-beta (TGF- $\beta$ ), and even microbial peptides such as lipopolysaccharides and formyl-methionyl peptides [15-17]. At this phase, mast cells play an important role on leukocyte recruitment, as they release other potent chemoattractants, such as tumor necrosis factor (TNF), histamine, proteases, leukotrienes, and cytokines [18].

As monocytes migrate to the wounded area, they differentiate into larger phagocytic macrophages. Monocyte/macrophage-specific chemotatic agents, monocyte chemoattractant protein-1 (MCP-1) [19] and macrophage inflammatory protein-1 (MIP-1) [20], are responsible for further monocyte homing.

At the wound site, neutrophils and macrophages bind to specific proteins of the extracellular matrix and phagocyte microorganisms, foreign particles and cell debris, controlling and fighting infection. At the same time, these cells also secrete specific chemoattractants, cytokines, growth factors and reactive oxygen and nitrogen species that mediate a cascade of events to induce granulation tissue formation. TNF$\alpha$, interleukin-1 (IL-1), interleukin-6 (IL-6), PDGF, transforming growth factor alpha (TGF- $\alpha$ ), TGF- $\beta$, epidermal growth factor (EGF), basic-fibroblast growth factor (b-FGF), vascular endothelial growth factor (VEGF), and nitric oxide (NO) are some of the substances released by macrophages and/or by neutrophils that contribute to the activation, proliferation and migration of fibroblasts and ECs from the adjacent dermis $[5,21,22]$. Therefore, this inflammatory cell influx is crucial in the transition between the processes of inflammation and the actual repair phase. A highly regulated, self-limited inflammatory response is necessary for proper wound healing. PMNs responsiveness is controlled in time, space and magnitude by apoptosis and/or by macrophagemediated phagocytosis.

The macrophage is classically considered the principal inflammatory cell in wound healing. Besides clearing the excessive neutrophils from the wounded area, they appear to be the main source of the growth factors cocktail that is required for granulation tissue formation. The observations that, in the absence of massive infection, wound healing is not affected in neutropenic animals, whereas animals deprived of macrophages presented a severe impairment of the wound healing machinery, gave rise to the "macrophage dogma" [23]. Other studies also support the importance of these cells in wound repair [24-26].

Nevertheless, this concept has been challenged by different evidences, including: a) the observation that wound repair in early embryos, where there is no inflammatory cell influx to the wound site, is virtually perfect [27,28]; b) the well known fact that in some dermatopathological settings of intense local accumulation of neutrophils and/or macrophages wound healing is abrogated; c) the finding that transgenic mice constitutively expressing the chemokine IP-10 and exhibiting an elevated inflammatory response show impaired granulation tissue formation and delayed wound healing [29].

Therefore, PMNs and monocytes/macrophages may be necessary for wound healing, however, under certain circumstances, skin repair may occur in their absence, or be impaired in case of an excessive response of these inflammatory cells.

\section{DIABETES AND INFLAMMATION}

A diabetes setting, either of type 1 or type $2 \mathrm{DM}$, is characterized by sustained hyperglycemia and chronic elevation of pro-inflammatory mediators. This pro-inflammatory environment induces and perpetuates the inflammatory responses, leading to a chronic inflammatory state. However, this condition is considered a low-grade inflammation, since the hyperglycemic background drives to impaired cellular defense mechanisms. 
Studies have shown that in the serum of type 2 diabetes patients, many pro-inflammatory substances, such as TNF- $\alpha$, IL-6 and IL-1 are elevated and have been linked to the development of insulin resistance [30,31]. In addition, analysis of the fluid of diabetic wounds from both animal models and human patients has shown insulin-degrading activity, which has in turn been correlated with the levels of haemoglobin A1c [32]. This suggests a straight relationship between hyperglycemia and the wound proteolytic environment. Also, in diabetes, neutrophils show a reduction in chemotatic and phagocytic activities, rendering the wounds more prone to infection $[33,34]$.

As a result, and in contrast to normal wound healing, where inflammation occurs in a sequential, regulated and self-resolving manner, the immune reaction in diabetic wounds appears prolonged and non-effective.

\section{NEOVASCULARIZATION IN WOUND HEALING}

In normal mature tissues the vessels are in general quiescent as tissue cells produce low levels of pro-angiogenic molecules and high levels of angiogenesis inhibitors. In the presence of skin injury, platelets, inflammatory cells, fibroblasts and injured EC secrete angiogenic factors that trigger the formation of new blood vessels within the granulation tissue. Neovascularization of the wound's granulation tissue occurs as a result of angiogenesis and/or vasculogenesis [35].

\section{ANGIOGENESIS}

Angiogenesis is the process by which resident EC of the wound's adjacent mature vascular network, in response to angiogenic signals, proliferate, migrate, and remodel into new capillaries that grow within the wound substrate [3539].

A vast array of molecules, including growth factors, extracellular matrix proteins (ECM), matrix metalloproteinases (MMPs), integrins and cytokines, interplay co-ordinately in highly complex scenarios to re-establish the vasculature at the injured site.

Wound-induced hypoxia (low oxygen tension) stimulates vascular regeneration by activating hypoxia-inducible transcription factors (HIF-1 $\alpha$ ), which increase the production of angiogenic growth factors such as VEGF [40,41] and the expression of the chemokine receptor CXCR4 [42]. Also, platelets secrete PDGF [43], VEGF [44], bFGF/FGF-2 [45], TGF- $\beta$ [45] and angiopoietin-1 (Ang-1) [46]. Moreover, activated fibroblasts, inflammatory cells, keratinocytes and even EC are capable of producing growth factors and cytokines. Together, these molecules create a potent angiogenic signal that stimulates EC proliferation and migration [47-49]. VEGF and FGF-2 are the main stimulators of blood vessels formation. FGF-2 is believed to be an early trigger of angiogenesis, whereas VEGF seems to be responsible for the sustained neovascular growth.

Migration of EC to the wound site occurs as a result of vascular permeability, peri-endothelial support loss and disruption to the basal membrane [50]. Proteolytic enzymes, such as urokinase plasminogen activator and MMPs, are key effectors on this process [51]. MMPs digest specifically the ECM components of the provisional matrix and stimulate cell proliferation and migration, either directly through activation of EC or indirectly via interaction with adhesion molecules [51].

As EC enter the wound tissue, they must continue to proliferate, arrange three-dimensionally as channels and produce a basal lamina [52]. Fibroblasts produce ECM proteins that act as a scaffold support for the new vascular network, through which EC may migrate, and as a reservoir and modulator for growth factors such as FGF-2, VEGF and PDGF $[39,53]$.

Finally, PDGF-BB recruits vascular smooth muscles cells (VSMCs) and pericytes to provide stabilization and maturation of the neovasculature [54-56].

\section{VASCULOGENESIS}

Vasculogenesis is the process by which EPCs are recruited from the bone-marrow to the peripheral circulation and subsequently to the wound area, differentiate into mature $\mathrm{EC}$ and give rise to a vascular network de novo [57-59].

Bone marrow-derived EPCs (BM-EPCs) respond primarily to local tissue ischemia by following angiogenic chemokine gradients that stimulate EPCs recruitment and subsequent homing to the site of injury, where they participate in neovasculogenesis $[58,60,61]$. Under the hypoxic stimuli, VEGF is released and upregulates the production of NO in the bone marrow (BM) through the activation (phosphorylation) of the stromal BM nitric oxide synthase (NOS). In this process, the endothelial isoform of nitric oxide synthase (eNOS) plays a central role $[62,63]$. Elevated NO levels stimulate EPC production from the BM, proliferation and mobilization to the bloodstream, whereas the chemokine stromal cell-derived factor- $1 \alpha$ (SDF-1 $\alpha) / C X C R 4$ axis promotes the homing of these cells to the wound area.

In addition to VEGF, placental growth factor (PlGF) also exerts its vasculogenic effects through VEGF receptor 1 (VEGF-R1) and activates MMP-9. MMP-9 stimulates the secretion of soluble kit-ligand (sKitL) from the membranebound mKitL on EPCs. This signal contributes to EPC proliferation, recruitment and maturation [64].

Furthermore, adhesion molecules, such as selectins and $\beta$-integrins, as well as activated platelets promote adhesion and differentiation of EPCs $[65,66]$. Vascular smooth muscle cells may also sequester circulating EPCs through chemokine secretion [67]. Once recruited and firmly adhered to the site of injury, EPCs contribute to the maintenance of the endothelial monolayer but also exert paracrine effects by producing angiogenic growth factors, which in turn promote mobilization of adjacent mature EC [68].

\section{ANGIOGENESIS AND DIABETIC WOUND HEALING}

The control of vascular growth has clinical importance since several disease states are associated with imbalances in blood vessel formation, such as diabetes mellitus. Patients with diabetes show abnormal angiogenesis in various organs. Vasculopathies associated with diabetes include increase in blood vessel formation (e.g. retinopathy, nephropathy) and accelerated atherosclerosis leading to coronary artery disease, peripheral vascular disease, and cerebrovascular disease [69]. However, in diabetes impaired wound healing angiogenesis is decreased [70], and this limited penetration 
of new blood vessels into the wound restricts the entry of inflammatory cells. In turn, the total amount of factors released by these cells will be decreased. A number of growth factors essential for wound healing, including FGF-2 and PDGF, have also been found to be reduced in experimental diabetic wounds [71-74]. Also, Topical administration of high glucose to wounds of non-diabetic rats was shown to inhibit the normal angiogenic process [75], suggesting a direct role for high glucose levels in diminished angiogenesis in diabetes.

VEGF, which plays an important role in vascular growth, has been shown to be deficient in experimental and clinical diabetic wounds [76]. Studies in diabetic animals have shown that modulation of oxidative damage [77] or inhibition of the receptor for advanced glycation end products [78] improve wound healing and were associated with the upregulation of endogenous VEGF. Moreover, VEGF administration improves healing in nondiabetic ischemic wounds [79] and blocking VEGF with neutralizing antibodies impedes tissue repair [80]. Together, these evidences support the notion that VEGF is critical for repair in impaired healing states and that the addition of VEGF could have a potential clinical use [76,81]. In fact, Galiano and collaborators [82] found that topical VEGF accelerates wound healing in a diabetic mouse model.

In conclusion, inflammation and neovascularization are essential for wound healing. However, these phenomena must be sequential, self-limited and highly controlled through orchestrated cell-molecule interactions, in order to achieve proper wound healing. In a diabetes setting, abnor- mal wound healing occurs as a result of a blunted acute inflammatory response and an impaired angiogenesis (Fig. 1).

\section{ENDOTHELIAL PROGENITOR CELLS AND DIA- BETIC WOUND HEALING}

Angiogenesis is not the only mechanism by which new vessels are formed, as explained before. EPCs are mobilized in response to trauma or ischemia and are able to contribute to tissue repair and new blood vessel formation [58,83-85]. Increasing evidence suggest that wound-healing mechanisms, in both the bone marrow and within the skin wound, are compromised by diabetes as a result of impaired bone marrow-derived EPCs [86-91]. It was demonstrated that EPCs isolated from diabetic patients have impaired proliferation, adhesion, and incorporation into vascular structure [90]. Also, the numbers of EPCs are decreased in diabetic patients $[89,90]$ and EPC recruitment into the wound site after vascular injury is also impaired in diabetes [92]. These alterations are likely to be involved in the pathogenesis of vascular disease in diabetes [86].

Growth factor such as VEGF can induce the release of progenitor cells from the bone marrow. However, the nonspecific effects of these growth factors in other cells, such as white cells and platelets, or the leaky-capillary effect raise concerns in using these factors to treat diabetic patients with nonhealing chronic wounds [93-96].

EPCs are mobilized by eNOS activation in the bone marrow. This process is possibly impaired in diabetes since eNOS activity was shown to be decreased in diabetic mice [60], thus preventing EPCs from reaching the wound site in

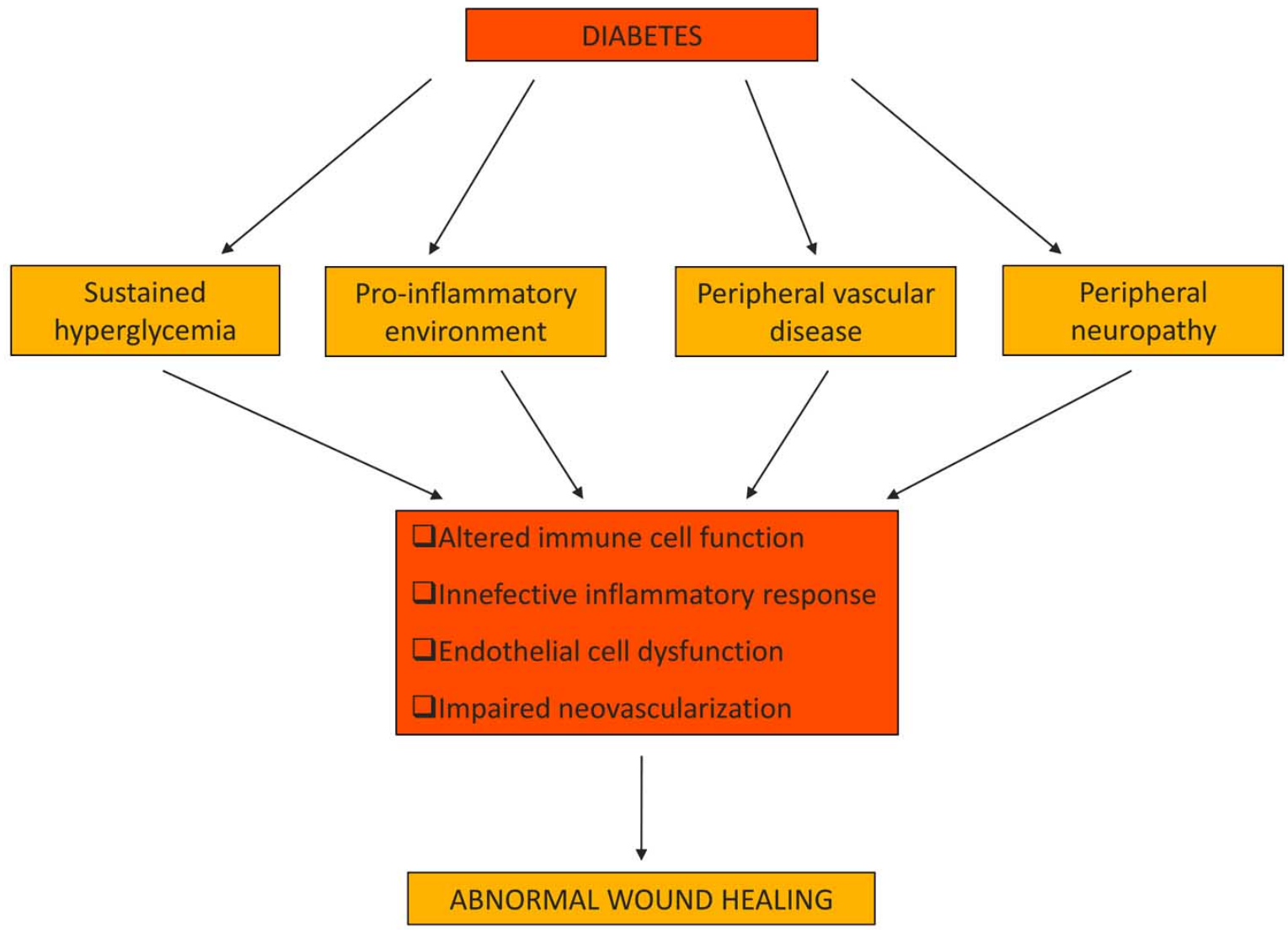

Fig. (1). Overview of diabetes impaired wound healing. 
significant numbers. Hyperoxia has been shown to stimulate eNOS activation in some tissues [97]. Although the total numbers of active EPCs were much lower in diabetic mice than in controls, hyperoxia showed to increase the mobilization of EPCs from the bone marrow to the bloodstream. An increase in bone marrow eNOS activation as a result of hyperoxia leads to EPC mobilization into the bloodstream [60]. However, hyperoxia is not effective in the EPC mobilization to the wound site as this process is related with signals that attract and stimulate these cells to migrate to sites of injury. EPC recruitment to the wound site depends on ischemiainduced upregulation of SDF- $1 \alpha$. The expression of SDF- $1 \alpha$ was found to be decreased in epithelial cells derived from wounds of streptozocin-induced diabetic mice [60] and this effect was found to be responsible for a decreased EPC recruitment to the wound site. More important, in combination with hyperoxia, which brings an increased amount of circulating EPCs, the local injection of recombinant SDF-1 $\alpha$ protein significantly enhances EPC recruitment to wound tissues and improves wound healing in diabetic animals [60].

\section{NEUROPEPTIDES AND WOUND HEALING}

The peripheral nervous system (PNS), acting through neuropeptides, not only relays sensory information to the central nervous system (CNS) but also plays a role in the inflammatory, proliferative, and reparative processes after injury. Neuropeptides mediate their actions by binding to specific receptors found on various cells in the skin, including immune cells, Langerhans cells, EC, mast cells, fibroblasts and keratinocytes [98]. Several neuropeptides are involved in wound healing, including substance P (SP), neuropeptide Y (NPY) and calcitonin gene-related peptide (CGRP) [99-101] (Table 1).

\section{SUBSTANCE $P$}

Substance $\mathrm{P}$, an 11-amino acid peptide, is a member of a family of structurally related peptides called tachykinins. Substance $\mathrm{P}$ is present in many areas of the CNS and PNS. In the periphery, SP is located especially in areas of immunologic importance, such as the skin, gastrointestinal tract, and respiratory tract [102]. Substance $\mathrm{P}$ is synthesized in the dorsal root ganglia, from which it migrates centrally to the dorsal horn of the spinal cord and peripherally to nerve terminals of sensory neurons [103]. The tachykinins bring about their actions mainly by activating 3 primary types of receptors: NK1, NK2, and NK3. All 3 receptors are members of the superfamily of receptors coupled to G-regulatory pro- teins. Receptor stimulation leads to the activation of phospholipase $\mathrm{C}$ and thus to the generation of inositol triphosphate and diacylglycerol and to the release of $\mathrm{Ca}^{2+}$ from internal stores [104-106].

\section{ALTERATION OF SUBSTANCE P IN DIABETES}

Morphological and immunohistochemical studies in type 1 diabetic subjects have shown a depletion of SP in the central and peripheral nervous system, especially in those with diabetic neuropathy [107]. Also, the number of SP-positive fibers are decreased in the dermis of diabetic patients with diabetic neuropathy [108]. Moreover, Gibran and collaborators [109] have demonstrated that exogenous SP improves wound healing kinetics in diabetic $\mathrm{db} / \mathrm{db}$ mice and they have also demonstrated fewer nerves in the epidermis of skin from diabetic patients and from $\mathrm{db} / \mathrm{db}$ mice. These results suggest that insufficient nerve-derived mediators such SP contribute to the impaired response to injury.

The biological action of substance $\mathrm{P}$ is regulated by a cell surface metallopeptidase, neutral endopeptidase (NEP), which degrades SP. The skin of diabetic patients with diabetic neuropathy was found to have an elevated NEP activity that may contribute to deficient neuroinflammatory signaling and impair wound healing [110]. Also, the skin from diabetic $\mathrm{db} / \mathrm{db}$ mice have an increased NEP activity and NEP inhibition was found to improve wound closure kinetics [111].

\section{SUBSTANCE P CONTRIBUTION TO INFLAMMA- TION AND ANGIOGENESIS IN WOUND HEALING}

Substance $\mathrm{P}$ is released by the sensory nerve fibers during tissue insult and it modulates responses in the skin by activating a number of target cells via neurokinin receptors. Substance P and other tachykinins are able to cause vasodilation because of direct actions on vascular smooth muscle and enhanced production of nitric oxide by the endothelium $[112,113]$. In addition, SP can initiate increased vascular permeability and protein extravasation after tissue injury $[114,115]$, enhancing leukocyte infiltration to tissues [102]. Also, SP acts as a strong chemoattractant for immune cells. SP can stimulate the production of TNF- $\alpha$, IL-1 $\beta$, IL-2, IL-8 and IL-6 from T cells, macrophages and neutrophils [116] and it modulates leukocyte adhesion to microvascular EC in the skin [117] by the upregulation of cell adhesion molecules, such as intracellular adhesion molecule (ICAM)-1, vascular cell adhesion molecule (VCAM)-1, P-selectin, leukocyte-function-associated antigen (LFA)-1 in EC and lymphocytes, essentially through intracellular $\mathrm{Ca}^{2+}$ mobilization

Table 1. Effect of Neuropeptides on Cutaneous Wound Healing (Adapted from Pradhan and Colleagues [176])

\begin{tabular}{|c|c|c|c|}
\hline Neuropeptide & Factors Involved & Function & $\begin{array}{c}\text { Involved in which Wound } \\
\text { Healing Phase }\end{array}$ \\
\hline Substance P (SP) & $\begin{array}{c}\text { TNF- } \alpha, \text { IL-1b, IL-2, IL-8, IL-6, } \\
\text { TGF- } \beta \text {, ICAM-1, VCAM-1, LFA-1, } \\
\text { Nitric oxide }\end{array}$ & $\begin{array}{l}\text { Vasodilation, vascular permeability, leu- } \\
\text { kocyte attraction and adhesion, cell prolif- } \\
\text { eration and migration }\end{array}$ & $\begin{array}{l}\text { Inflammation } \\
\text { Angiogenesis }\end{array}$ \\
\hline Neuropeptide Y (NPY) & IL-2 and TNF- $\alpha$ & $\begin{array}{l}\text { Migration of macrophages } \\
\text { Cell proliferation }\end{array}$ & $\begin{array}{l}\text { Inflammation } \\
\text { Angiogenesis }\end{array}$ \\
\hline $\begin{array}{c}\text { Calcitonin gene-related peptide } \\
\text { (CGRP) }\end{array}$ & $\begin{array}{c}\text { IL- } 1 \alpha, \text { IL- } 1 \beta, \text { IL- } 8, \text { IL- } 2, \text { IL-6, TNF- } \\
\alpha, \text { VEGF }\end{array}$ & $\begin{array}{l}\text { Vasodilation, vascular permeability, cell } \\
\text { proliferation, acts in combination with SP }\end{array}$ & Needs investigation \\
\hline
\end{tabular}


and NF-AT- and NF- $\kappa$ B pathways [118-123]. The leukocytes that extravasate to the tissues after injury will promote a proinflammatory microenvironment that leads to proliferation of EC and angiogenesis.

Results show that SP can have a trophic function in wound healing by the stimulation of angiogenesis. SP was shown to mediate wound healing, after UV-induced damage of the skin, by stimulation of angiogenesis or epidermal cell proliferation [124]. Moreover, substance P stimulated angiogenesis in an in vitro model using human umbilical cord vein EC cultured on a basement membrane (Matrigel) substrate and it stimulates EC differentiation into capillary-like structures in a dose-dependent manner [117]. Capillary and fibroblast proliferation were found to be accelerated by SP after operative repair of the Achilles tendon in rats [125]. In addition, elevated glucose and fatty acid levels as seen with diabetes mellitus, were found to inhibit SP mediated human microvascular endothelial cell (HMEC-1) directional migration and proliferation [126].

Substance P plays a major role in the inflammatory and angiogenesis phases of wound healing, and dysregulation of the SP pathway in diabetes can impair wound healing.

\section{NEUROPEPTIDE Y}

NPY is a highly conserved polypeptide composed of 36 aminoacids [127] and it is widely present in the CNS and PNS. NPY regulates multiple physiological processes including hypothalamic control of food intake, anxiety [128], and modulate the immune function [129]. NPY is not only expressed in the nervous system, but also by the heart, immune cells and EC [130-134]. The NPY acts trough NPY receptors. The cDNAs of four NPY receptors have been cloned: Y1, Y2, Y4 and Y5. These receptors mediate their responses through $\mathrm{G}$ proteins, resulting in inhibition of adenylate cyclase activity and increase in intracellular $\left[\mathrm{Ca}^{2+}\right]$ [135]. NPY regulates vasoconstriction and stimulates vascular smooth muscle cell proliferation [136]. Also, it inhibits T cell activation modulating the inflammatory signal [137]. Moreover, NPY stimulates proliferation, migration and formation of EC [138].

\section{ALTERATION OF NEUROPEPTIDE Y IN DIABETES}

The levels of NPY in the CNS, particularly in the hypothalamus, were found to be increased in diabetic patients [139], however, in the skin, the NPY levels showed to be reduced in diabetic patients [140-142]. Also, the expression of NPY was shown to be reduced in diabetic rats [143]. Moreover, it was shown a diminished contractile response to NPY of arteries from diabetic rabbits [144].

\section{NEUROPEPTIDE Y CONTRIBUTION TO INFLAM- MATION AND ANGIOGENESIS IN WOUND HEAL- ING}

NPY has pleiotropic effects on both the innate and adaptive immune system, acting through Y1 receptor, with effects ranging from the modulation of cell migration to macrophage, T helper (Th) cell cytokine release, and antibody production [145]. NPY was shown to stimulate proliferation and migration of EC [146,147]. In HUVECs, NPY was shown to be co-localized with dipeptidyl peptidase IV (DPPIV) which cleaves NPY(1-36) to form NPY(3-36) resulting in the for- mation of a non-Y1 receptor agonist, which remains angiogenic. The blockage of DPPIV by using monoclonal antibodies showed to decrease the migration of HUVECs in response to NPY(1-36) or NPY(3-36) following cell wounding. These results suggest that non-Y1 receptors activated by NPY(3-36) mediate angiogenic effects of NPY [146]. Also, Y2 receptor and DPPIV expression was significantly reduced in ageing mice [148]. Moreover, mice with deleted Y2 receptor showed to have a delayed wound healing caused by the blockage of NPY-induced angiogenesis [100]. In conclusion, NPY is also important for both the inflammatory and angiogenic phases of wound healing.

\section{CALCITONIN GENE-RELATED PEPTIDE}

Calcitonin gene-related peptide, a 37-amino acid peptide, is known to be generated from the alternative splicing of the calcitonin gene, both in the CNS and the PNS [149]. CGRP is released together with SP from peripheral sensory nerves $[150,151]$. The CGRP receptors were shown to be present in the brain and also in other organs such as heart, vasculature, liver, spleen, skeletal muscle and lung, and in lymphocytes [149]. Pharmacologically, a two CGRP1 and CGRP2 receptor subtypes has been proposed [152]. Stimulation of CGRP receptors in various cells and tissue has been shown to increase intracellular cyclic adenosine monophosphate (cAMP) and to activate adenylate cyclase [149]. Peripheral secretion of CGRP causes prolonged increases in blood flow [153]. Unlike SP, CGRP is not capable of enhancing vascular permeability on its own but potentiates the protein extravasation induced by tachykinins $[154,155]$.

\section{ALTERATION OF CGRP IN DIABETES}

CGRP is reduced in the heart, dorsal root ganglion and in primary sensory neurons of diabetic animal models [156158]. Also, both CGRP and CGRP receptor expression were shown to be reduced in a diabetic cardiomyopathy model $[159,160]$. Moreover, the function of CGRP is altered in diabetes and recent studies have shown that CGRP-mediated vasodilation is significantly reduced in diabetic rats [161163].

\section{CGRP CONTRIBUTION TO INFLAMMATION AND ANGIOGENESIS IN WOUND HEALING}

CGRP is known to induce neurogenic inflammation, inducing pro-inflammatory response in several cell types, and it also induces the formation of new vessels, important during physiological and pathophysiological wound healing [101,164]. CGRP induces inflammatory pathways but also inflammation can induce CGRP release $[165,166]$. The proinflammatory action of CGRP includes the stimulation of the adhesion of immune cells to EC [167], the induction of vasodilation, plasma extravasation, and the expression of adhesion molecules on vascular EC [167-169]. CGRP also regulates cytokine production. Keratinocytes were shown to increase the release of IL- $1 \alpha$ and IL- 8 induced by CGRP [170]. CGRP also inhibits IL-2 production from T lymphocytes [171] and increases, in combination with SP, the levels of IL-1 $\beta$, IL- 6 and TNF- $\alpha$ in human dental pulp fibroblasts and IL-1 $\beta$ and TNF- $\alpha$ in macrophages $[172,173]$. CGRP can also stimulate the proliferation of keratinocytes, EC and melanocytes [164,174,175]. In CGRP knockout mice (CGRP-/-), angiogenesis and wound healing were impaired 
compared with those in wild-type mice, and a decrease in the release of VEGF from the wound granulation tissues was shown [101]. This suggests that the involvement of CGRP in wound healing is mediated through its effect on angiogenesis. Therefore, CGRP derived from neuronal systems may facilitate wound healing and angiogenesis.

\section{FUTURE THERAPIES}

\section{Growth Factors}

The complex sequences of molecular and cellular events that are carefully orchestrated during wound healing are difficult to reproduce. Nevertheless, administration of growth factors has been shown to promote healing by affecting all phases of wound healing. Several growth factors have been studied for the promotion of diabetic wound healing, such as FGF [177-179], VEGF [48,82], granulocyte colonystimulating factor [180-182], and hepatocyte growth factor [175,183-187]. Despite high expectations in laboratory models of wound healing, growth factor delivery has shown to have a limited clinical success. However, PDGF-BB was shown to be an exception being successful in promoting wound healing in clinical trials, resulting in the first growth factor delivery product, Regranex ${ }^{\circledR}$, approved by the Food and Drug Administration for treatment of diabetic foot ulcers $[188,189]$. The difficulty other growth factors in being successful can be attributed, at least in part, to their short halflive [190], which is due to the rapid degradation in the protease-rich environment of the wound leading to a decrease bioactivity [191]. Another reason for le lack of therapeutic effect may be correlated with the use of single growth factors. The judicious combination of several growth factors or with other wound healing therapeutic strategies may be necessary to achieve better clinical results.

\section{Gene Therapy}

The skin has become an important target of gene therapy research because it is accessible and the effects of therapy can be easily monitored. Also, this research was made possible due to the harvest and cultivation ease of fibroblast and keratinocyte, thus allowing in vitro testing for gene transfer and the use of skin cells as vehicles in gene transfer [192]. Gene delivery has also been explored as an alternative to growth factor delivery because infiltrating cells uptake the genes and produce continuously the therapeutic protein(s) in the local environment [193,194].

Several methods of gene delivery have been studied. Viral vectors are the original and most established technology for gene delivery, including adenovirus and lentivirus. A wide range of applications have been developed and many virus-mediated gene transfer models are successful. The production of viral vectors, however, is time and cost consuming, transfection efficacy is variable, and the risk of local or systemic infections remains a concern. Non-viral gene therapy, which is performed without a viral vector, includes the use of naked DNA, liposomes, electroporation or biomaterials. This approach can eliminate the risk of infection and cost of vector production. The transient nature of gene expression is also a benefit in wound healing applications.

Adenoviral delivery of PDGF-B has been shown to significantly enhance wound closure, granulation tissue formation and vessel density in $\mathrm{db} / \mathrm{db}$, streptozotocin, and non- obese diabetic (NOD) mice [87]. Interestingly, lentiviral delivery of the gene encoding PDGF-B also enhanced angiogenesis and collagen deposition in diabetic wounds but did not affect re-epithelialization [195]. Adenoviral delivery of Ang-1 was also shown to improve wound repair in diabetic mice by inducing angiogenesis in a VEGF-independent manner [196]. Moreover, lentiviral-mediated transfection of SDF-1 $\alpha$ in diabetic mice also improve wound healing [197]. The use of a fibrin scaffold was shown to provide an enhanced method of gene transfer of adenovirus encoding eNOS, compared with direct delivery of adenovirus encoding NOS alone and fibrin scaffold alone. This is due to the ability of fibrin to retain the vector at the wound site, and present the adenovirus to infiltrating cells involved in wound healing. The eNOS gene delivery showed to increase nitric oxide production and improve wound healing, as shown by improving epithelialization, maturation of angiogenesis and inflammatory response [198].

Electroporation has been successfully used to accelerate the closure of diabetic wounds [199]. Also, it was shown that the synergistic use of electroporation, where an electric field is applied to tissue, in combination with TGF- $\beta 1$ cDNA improves wound healing, in a diabetic mouse model, showing an increased rate of re-epithelialization, angiogenesis, and collagen synthesis [200]. Moreover, the electroporation and simultaneous administration of keratinocyte growth factor (KGF) plasmid DNA showed to increase wound healing [201].

These techniques need further investigation to define their efficacy and clinical applicability. Also, it is important to study the growth factor levels in different phases of wound healing and to elucidate the precise timing of gene expression or downregulation required to better improve wound healing.

\section{CELL-BASED THERAPIES}

Cell-based therapy is a promising therapeutic option for treating patients with diabetic, nonhealing wounds. Several studies have investigated the potential of stem cells, keratinocytes, and fibroblasts for the treatment of chronic wounds. However, little is known about the use of most of these cells in diabetic wounds, and the only FDA-approved treatments include fibroblasts delivered in an absorbable mesh [202], and fibroblasts and keratinocytes delivered in type 1 collagen [203].

The use of stem cells in diabetic wounds has been studied only in animal models with relative efficacy. Bone-marrow mesenchymal stem cells (BM-MSC) are capable of selfrenewing and of differentiating into various tissues and cells, such as liver epithelium, lung, gastrointestinal tract, and skin cells $[204,205]$. In fact it was shown that allogeneic BMMSCs significantly enhanced wound healing in normal and diabetic mice through differentiation and release of proangiogenic factors [206]. Moreover, CD34+ cells were shown to improve the healing of diabetic wounds with an increase in revascularization [207]. EPCs are one type of cells that have been moved from experimental models to clinical trials. EPCs seem to be ideal candidates for in vivo cell based therapies for ischemia. However, EPCs from diabetic patients have been shown to be dysfunctional with impaired proliferation, adhesion, and incorporation into vascular struc- 
tures, thus, autologous EPCs could be of limited use $[90,208]$. The efficacy of cell therapies to augment neovascularization and healing depends not only on the sufficient amount of circulating EPCs, but also on the efficient recruitment of these cells to the target tissue. Therapeutic interventions, including correcting both EPC activation via hyperoxia and EPC homing via administration of SDF-1 $\alpha$, may significantly accelerate diabetic wound healing by correcting the EPC deficit inherent to diabetic wounds. If simultaneously combined with current therapies, and with other potential treatments targeting eNOS activation and EPC recruitment, might further stimulate healing. A better understanding of the molecular and cellular mechanisms of nonhealing diabetic wounds in combination with development of efficient approaches for correcting EPC deficits and functional impairments will potentially result in the development of efficient therapies that prevent wound progression, eliminate amputations, and promote rapid healing in patients with diabetes.

\section{NEUROPEPTIDES}

The immune system is normally regarded as self regulating, but several studies suggest that the peripheral nervous system closely interacts with the immune system and that it plays important neuroimmuno regulatory functions $[209,210]$. Afferent nerves can respond to a large range of stimuli and, upon stimulation, neuropeptides are rapidly released in the microenvironment $[209,210]$. In skin, these neuropeptides act through the activation of receptors present in a variety of cells, including microvascular EC, keratinocytes, mast cells, fibroblasts, and immune cells. Impaired neurogenic inflammation, due to diabetic neuropathy, contributes to enhanced susceptibility for diabetic foot ulcer. The neuropeptides known to be involved in impaired diabetic wound healing are substance $\mathrm{P}[99,211]$ and neuropeptide Y [100,212]. Further research is needed in order to evaluate the effect of the addition of neuropeptides to impaired wound healing and possibly consider this approach as a future therapy.

\section{CONCLUSION}

Despite the studies on chronic diabetic wounds, the problem persists and the success of currents treatments is limited. The complex molecular events that underlie successful wound healing limits the effectiveness of the treatments and thus monotherapy is not the better option. Novel discoveries of disease molecular pathogenesis from studies of patient biopsies and animal models by using molecular analyses, such as genomics and proteomics, and the use of transgenic mice, will lead to a better understanding of deficient wound healing in diabetes. These new findings with the development of systems for sustained topical delivery (such as polymers, gene delivery systems), and major advances in tissue engineering (such as human skin engineering, cellular matrices, and cell-based therapies), hold the promise of the potential application of these technologies to people with diabetic wounds in the near future. Eventually, the development of a combination of treatments that ensures rapid and complete healing is the key strategy for the management of chronic nonhealing diabetic wounds.

\section{ACKNOWLEDGEMENT}

Grant Support: EFSD/JDRF/Novo Nordisk European Programme in Type 1 Diabetes Research (EC), FCT POCTI/SAU-MMO/57598/2004 (EC) and PTDC/SAUMII/098567/2008, SFRH/BPD/46341/2008 (EL), Albert Renold Fellowship (EFSD) (EL) and Instituto Gulbenkian de Ciencia (EL), SFRH/BD/48624/2008 (AT).

\section{REFERENCES}

[1] No author listed. Economic costs of diabetes in the U.S in 2007. Diabetes Care, 2008, 31, 596-615.

[2] No author listed. Consensus Development Conference on Diabetic Foot Wound Care: 7-8 April 1999, Boston, Massachusetts. American Diabetes Association. Diabetes Care, 1999, 22, 1354-60.

[3] No author listed. Epidemiology of lower extremity amputation in centres in Europe, North America and East Asia. The Global Lower Extremity Amputation Study Group. Br. J. Surg., 2000, 87, 328-37.

[4] Falanga, V. Wound healing and its impairment in the diabetic foot. Lancet, 2005, 366, 1736-43.

[5] Singer, A.J.; Clark, R.A. Cutaneous wound healing. N. Engl. J. Med., 1999, 341, 738-46.

[6] Galkowska, H.; Olszewski, W.L.; Wojewodzka, U.; Rosinski, G.; Karnafel, W. Neurogenic factors in the impaired healing of diabetic foot ulcers. J. Surg. Res., 2006, 134, 252-8.

[7] Apelqvist, J.; Larsson, J.; Agardh, C. D. The importance of peripheral pulses, peripheral oedema and local pain for the outcome of diabetic foot ulcers. Diabet. Med., 1990, 7, 590-4.

[8] Armstrong, D.G.; Lavery, L.A.; Harkless, L.B. Validation of a diabetic wound classification system. The contribution of depth, infection, and ischemia to risk of amputation. Diabetes Care, 1998, 21, 855-9.

[9] Moulik, P.K.; Mtonga, R.; Gill, G.V. Amputation and mortality in new-onset diabetic foot ulcers stratified by etiology. Diabetes Care, 2003, 26, 491-4.

[10] Oyibo, S.O.; Jude, E.B.; Tarawneh, I.; Nguyen, H.C.; Armstrong, D.G.; Harkless, L.B.; Boulton, A.J. The effects of ulcer size and site, patient's age, sex and type and duration of diabetes on the outcome of diabetic foot ulcers. Diabet. Med., 2001, 18, 133-8.

[11] Prompers, L.; Schaper, N.; Apelqvist, J.; Edmonds, M.; Jude, E.; Mauricio, D.; Uccioli, L.; Urbancic, V.; Bakker, K.; Holstein, P.; Jirkovska, A.; Piaggesi, A.; Ragnarson-Tennvall, G.; Reike, H.; Spraul, M.; Van Acker, K.; Van Baal, J.; Van Merode, F.; Ferreira, I.; Huijberts, M. Prediction of outcome in individuals with diabetic foot ulcers: focus on the differences between individuals with and without peripheral arterial disease. The EURODIALE Study. Diabetologia, 2008, 51, 747-55.

[12] Jude, E.B.; Oyibo, S.O.; Chalmers, N.; Boulton, A.J. Peripheral arterial disease in diabetic and nondiabetic patients: a comparison of severity and outcome. Diabetes Care, 2001, 24, 1433-7.

[13] No author listed. The effect of intensive insulin treatment of diabetes on the development and progression of long-term complications in insulin-dependent diabetes mellitus. The Diabetes Control and Complications Trial Research Group. N. Engl. J. Med., 1993, 329, 977-86.

[14] Adler, A.I.; Boyko, E.J.; Ahroni, J.H.; Stensel, V.; Forsberg, R.C.; Smith, D.G. Risk factors for diabetic peripheral sensory neuropathy. Results of the Seattle Prospective Diabetic Foot Study. Diabetes Care, 1997, 20, 1162-7.

[15] Acosta, J.B.; del Barco, D.G.; Vera, D.C.; Savigne, W.; LopezSaura, P.; Guillen Nieto, G.; Schultz, G.S. The pro-inflammatory environment in recalcitrant diabetic foot wounds. Int. Wound J., 2008, 5, 530-9.

[16] Engelhardt, E.; Toksoy, A.; Goebeler, M.; Debus, S.; Brocker, E.B.; Gillitzer, R. Chemokines IL-8, GROalpha, MCP-1, IP-10, and Mig are sequentially and differentially expressed during phasespecific infiltration of leukocyte subsets in human wound healing. Am. J. Pathol., 1998, 153, 1849-60.

[17] Gillitzer, R.; Goebeler, M. Chemokines in cutaneous wound healing. J. Leukoc. Biol., 2001, 69, 513-21.

[18] Noli, C.; Miolo, A. The mast cell in wound healing. Vet. Dermatol., 2001, 12, 303-13.

[19] Kunkel, S.L.; Standiford, T.; Kasahara, K.; Strieter, R.M. Stimulus specific induction of monocyte chemotactic protein-1 (MCP-1) gene expression. Adv. Exp. Med. Biol., 1991, 305, 65-71. 
[20] Sherry, B.; Tekamp-Olson, P.; Gallegos, C.; Bauer, D.; Davatelis, G.; Wolpe, S.D.; Masiarz, F.; Coit, D.; Cerami, A. Resolution of the two components of macrophage inflammatory protein 1 , and cloning and characterization of one of those components, macrophage inflammatory protein 1 beta. J. Exp. Med., 1988, 168, 22519 .

[21] Lewis, J.S.; Lee, J.A.; Underwood, J.C.; Harris, A.L.; Lewis, C.E. Macrophage responses to hypoxia: relevance to disease mechanisms. J. Leukoc. Biol., 1999, 66, 889-900.

[22] Steed, D.L. The role of growth factors in wound healing. Surg. Clin. North. Am., 1997, 77, 575-86.

[23] Leibovich, S.J.; Ross, R. The role of the macrophage in wound repair. A study with hydrocortisone and antimacrophage serum. Am. J. Pathol., 1975, 78, 71-100.

[24] DiPietro, L.A. Wound healing: the role of the macrophage and other immune cells. Shock, 1995, 4, 233-40.

[25] Subramaniam, M.; Saffaripour, S.; Van De Water, L.; Frenette, P.S.; Mayadas, T.N.; Hynes, R.O.; Wagner, D.D. Role of endothelial selectins in wound repair. Am. J. Pathol., 1997, 150, 1701-9.

[26] Werner, S.; Grose, R. Regulation of wound healing by growth factors and cytokines. Physiol. Rev., 2003, 83, 835-70.

[27] Clark, R.A. Epithelial-mesenchymal networks in wounds: a hierarchical view. J. Invest. Dermatol., 2003, 120, ix-xi.

[28] Nodder, S.; Martin, P. Wound healing in embryos: a review. Anat. Embryol. (Berl), 1997, 195, 215-28.

[29] Luster, A.D.; Cardiff, R.D.; MacLean, J.A.; Crowe, K.; Granstein, R.D. Delayed wound healing and disorganized neovascularization in transgenic mice expressing the IP-10 chemokine. Proc. Assoc. Am. Physicians, 1998, 110, 183-96.

[30] Borst, S. E. The role of TNF-alpha in insulin resistance. Endocrine, 2004, 23(2-3), 177-82

[31] Tilg, H.; Moschen, A.R. Inflammatory mechanisms in the regulation of insulin resistance. Mol. Med., 2008, 14, 222-31.

[32] Duckworth, W.C.; Fawcett, J.; Reddy, S.; Page, J.C. Insulindegrading activity in wound fluid. J. Clin. Endocrinol. Metab., 2004, 89, 847-51.

[33] Alba-Loureiro, T-C.; Hirabara, S.M.; Mendonca, J.R.; Curi, R.; Pithon-Curi, T.C. Diabetes causes marked changes in function and metabolism of rat neutrophils. J. Endocrinol., 2006, 188, 295-303.

[34] Marhoffer, W.; Stein, M.; Schleinkofer, L.; Federlin, K. Evidence of ex vivo and in vitro impaired neutrophil oxidative burst and phagocytic capacity in type 1 diabetes mellitus. Diabetes Res. Clin. Pract., 1993, 19, 183-8.

[35] Bauer, S.M.; Bauer, R.J.; Velazquez, O.C. Angiogenesis, vasculogenesis, and induction of healing in chronic wounds. Vasc. Endovascular. Surg., 2005, 39, 293-306.

[36] Bauer, S.M.; Bauer, R.J.; Liu, Z.J.; Chen, H.; Goldstein, L.; Velazquez, O.C. Vascular endothelial growth factor-C promotes vasculogenesis, angiogenesis, and collagen constriction in threedimensional collagen gels. J. Vasc. Surg., 2005, 41, 699-707.

[37] Hanahan, D. Signaling vascular morphogenesis and maintenance. Science, 1997, 277, 48-50.

[38] Liu, Z.J.; Snyder, R.; Soma, A.; Shirakawa, T.; Ziober, B.L.; Fairman, R.M.; Herlyn, M.; Velazquez, O.C. VEGF-A and alphaVbeta3 integrin synergistically rescue angiogenesis via N-Ras and PI3-K signaling in human microvascular endothelial cells. FASEB J., 2003, 17, 1931-3.

[39] Velazquez, O.C.; Snyder, R.; Liu, Z.J.; Fairman, R.M.; Herlyn, M. Fibroblast-dependent differentiation of human microvascular endothelial cells into capillary-like 3-dimensional networks. FASEB J., 2002, 16, 1316-8.

[40] Detmar, M.; Brown, L.F.; Berse, B.; Jackman, R.W.; Elicker, B.M.; Dvorak, H.F.; Claffey, K.P. Hypoxia regulates the expression of vascular permeability factor/vascular endothelial growth factor (VPF/VEGF) and its receptors in human skin. J. Invest. Dermatol., 1997, 108, 263-8.

[41] Maxwell, P.H.; Ratcliffe, P.J. Oxygen sensors and angiogenesis. Semin. Cell Dev. Biol., 2002, 13, 29-37.

[42] Kubo, M.; Li, T.S.; Kamota, T.; Ohshima, M.; Qin, S.L.; Hamano, $\mathrm{K}$. Increased expression of CXCR4 and integrin alphaM in hypoxia-preconditioned cells contributes to improved cell retention and angiogenic potency. J. Cell Physiol., 2009, 220, 508-14.

[43] Deuel, T.F.; Kawahara, R.S.; Mustoe, T.A.; Pierce, A.F. Growth factors and wound healing: platelet-derived growth factor as a model cytokine. Апnи. Rev. Med., 1991, 42, 567-84.
[44] Pintucci, G.; Froum, S.; Pinnell, J.; Mignatti, P.; Rafii, S.; Green, D. Trophic effects of platelets on cultured endothelial cells are mediated by platelet-associated fibroblast growth factor-2 (FGF-2) and vascular endothelial growth factor (VEGF). Thromb. Haemost., 2002, $88,834-42$.

[45] Slavin, J. The role of cytokines in wound healing. J. Pathol., 1996, 178, 5-10.

[46] Li, J.J.; Huang, Y.Q.; Basch, R.; Karpatkin, S. Thrombin induces the release of angiopoietin-1 from platelets. Thromb. Haemost., 2001, 85, 204-6.

[47] Battegay, E.J.; Rupp, J.; Iruela-Arispe, L.; Sage, E.H.; Pech, M. PDGF-BB modulates endothelial proliferation and angiogenesis in vitro via PDGF beta-receptors. J. Cell Biol., 1994, 125, 917-28.

[48] Nissen, N.N.; Polverini, P.J.; Koch, A.E.; Volin, M.V.; Gamelli, R.L.; DiPietro, L.A. Vascular endothelial growth factor mediates angiogenic activity during the proliferative phase of wound healing. Am. J. Pathol., 1998, 152, 1445-52.

[49] Thommen, R.; Humar, R.; Misevic, G.; Pepper, M.S.; Hahn, A.W.; John, M.; Battegay, E.J. PDGF-BB increases endothelial migration on cord movements during angiogenesis in vitro. J. Cell Biochem., 1997, 64, 403-13.

[50] Sephel, G.C.; Kennedy, R.; Kudravi, S. Expression of capillary basement membrane components during sequential phases of wound angiogenesis. Matrix Biol., 1996, 15, 263-79.

[51] Burbridge, M.F.; Coge, F.; Galizzi, J.P.; Boutin, J.A.; West, D.C.; Tucker, G.C. The role of the matrix metalloproteinases during in vitro vessel formation. Angiogenesis, 2002, 5, 215-26.

[52] Autiero, M.; De Smet, F.; Claes, F.; Carmeliet, P. Role of neural guidance signals in blood vessel navigation. Cardiovasc. Res., 2005, 65, 629-38.

[53] Feng, X.; Clark, R.A.; Galanakis, D.; Tonnesen, M.G. Fibrin and collagen differentially regulate human dermal microvascular endothelial cell integrins: stabilization of alphav/beta3 mRNA by fibrin 1. J. Invest. Dermatol., 1999, 113,913-9.

[54] Darland, D.C.; D'Amore, P.A. Blood vessel maturation: vascular development comes of age. J. Clin. Invest., 1999, 103, 157-8.

[55] Hirschi, K.K.; Rohovsky, S.A.; Beck, L.H.; Smith, S.R.; D'Amore, P.A. Endothelial cells modulate the proliferation of mural cell precursors via platelet-derived growth factor-BB and heterotypic cell contact. Circ. Res., 1999, 84, 298-305.

[56] Korff, T.; Kimmina, S.; Martiny-Baron, G.; Augustin, H.G. Blood vessel maturation in a 3-dimensional spheroidal coculture model: direct contact with smooth muscle cells regulates endothelial cell quiescence and abrogates VEGF responsiveness. FASEB J., 2001, 15, 447-57.

[57] Reyes, M.; Dudek, A.; Jahagirdar, B.; Koodie, L.; Marker, P.H.; Verfaillie, C.M. Origin of endothelial progenitors in human postnatal bone marrow. J. Clin. Invest., 2002, 109, 337-46.

[58] Takahashi, T.; Kalka, C.; Masuda, H.; Chen, D.; Silver, M.; Kearney, M.; Magner, M.; Isner, J.M.; Asahara, T. Ischemia- and cytokine-induced mobilization of bone marrow-derived endothelial progenitor cells for neovascularization. Nat. Med., 1999, 5, 434-8.

[59] Tepper, O.M.; Capla, J.M.; Galiano, R.D.; Ceradini, D.J.; Callaghan, M.J.; Kleinman, M.E.; Gurtner, G.C. Adult vasculogenesis occurs through in situ recruitment, proliferation, and tubulization of circulating bone marrow-derived cells. Blood, 2005, 105, 1068-77.

[60] Gallagher, K.A.; Liu, Z.J.; Xiao, M.; Chen, H.; Goldstein, L.J.; Buerk, D.G.; Nedeau, A.; Thom, S.R.; Velazquez, O.C. Diabetic impairments in NO-mediated endothelial progenitor cell mobilization and homing are reversed by hyperoxia and SDF-1 alpha. $J$. Clin. Invest., 2007, 117, 1249-59.

[61] Li, M.; Nishimura, H.; Iwakura, A.; Wecker, A.; Eaton, E.; Asahara, T.; Losordo, D.W. Endothelial progenitor cells are rapidly recruited to myocardium and mediate protective effect of ischemic preconditioning via "imported" nitric oxide synthase activity. Circulation, 2005, 111, 1114-20.

[62] Aicher, A.; Heeschen, C.; Mildner-Rihm, C.; Urbich, C.; Ihling, C.; Technau-Ihling, K.; Zeiher, A.M.; Dimmeler, S. Essential role of endothelial nitric oxide synthase for mobilization of stem and progenitor cells. Nat. Med., 2003, 9, 1370-6.

[63] Murohara, T.; Asahara, T.; Silver, M.; Bauters, C.; Masuda, H.; Kalka, C.; Kearney, M.; Chen, D.; Symes, J.F.; Fishman, M.C.; Huang, P.L.; Isner, J.M. Nitric oxide synthase modulates angiogenesis in response to tissue ischemia. J. Clin. Invest., 1998, 101, 2567-78. 
[64] Rafii, S.; Avecilla, S.; Shmelkov, S.; Shido, K.; Tejada, R.; Moore, M.A.; Heissig, B.; Hattori, K. Angiogenic factors reconstitute hematopoiesis by recruiting stem cells from bone marrow microenvironment. Ann. N. Y. Acad. Sci., 2003, 996, 49-60.

[65] Chavakis, E.; Aicher, A.; Heeschen, C.; Sasaki, K.; Kaiser, R.; El Makhfi, N.; Urbich, C.; Peters, T.; Scharffetter-Kochanek, K.; Zeiher, A.M.; Chavakis, T.; Dimmeler, S. Role of beta2-integrins for homing and neovascularization capacity of endothelial progenitor cells. J. Exp. Med., 2005, 201, 63-72.

[66] de Boer, H.C.; Verseyden, C.; Ulfman, L.H.; Zwaginga, J.J.; Bot, I.; Biessen, E.A.; Rabelink, T.J.; van Zonneveld, A.J. Fibrin and activated platelets cooperatively guide stem cells to a vascular injury and promote differentiation towards an endothelial cell phenotype. Arterioscler. Thromb. Vasc. Biol., 2006, 26, 1653-9.

[67] Zernecke, A.; Schober, A.; Bot, I.; von Hundelshausen, P.; Liehn, E.A.; Mopps, B.; Mericskay, M.; Gierschik, P.; Biessen, E.A.; Weber, C. SDF-1alpha/CXCR4 axis is instrumental in neointimal hyperplasia and recruitment of smooth muscle progenitor cells. Circ. Res., 2005, 96, 784-91.

[68] Urbich, C.; Aicher, A.; Heeschen, C.; Dernbach, E.; Hofmann, W.K.; Zeiher, A.M.; Dimmeler, S. Soluble factors released by endothelial progenitor cells promote migration of endothelial cells and cardiac resident progenitor cells. J. Mol. Cell Cardiol., 2005, 39, 733-42.

[69] Martin, A.; Komada, M.R.; Sane, D.C. Abnormal angiogenesis in diabetes mellitus. Med. Res. Rev., 2003, 23, 117-45.

[70] Brem, H.; Jacobs, T.; Vileikyte, L.; Weinberger, S.; Gibber, M.; Gill, K.; Tarnovskaya, A.; Entero, H.; Boulton, A.J. Woundhealing protocols for diabetic foot and pressure ulcers. Surg. Technol. Int., 2003, 11, 85-92.

[71] Beer, H.D.; Longaker, M.T.; Werner, S. Reduced expression of PDGF and PDGF receptors during impaired wound healing. J. Invest. Dermatol., 1997, 109, 132-8.

[72] Werner, S.; Breeden, M.; Hubner, G.; Greenhalgh, D.G.; Longaker, M.T. Induction of keratinocyte growth factor expression is reduced and delayed during wound healing in the genetically diabetic mouse. J. Invest. Dermatol., 1994, 103, 469-73.

[73] Bitar, M.S.; Labbad, Z.N. Transforming growth factor-beta and insulin-like growth factor-I in relation to diabetes-induced impairment of wound healing. J. Surg. Res., 1996, 61, 113-9.

[74] Brown, D.L.; Kane, C.D.; Chernausek, S.D.; Greenhalgh, D.G. Differential expression and localization of insulin-like growth factors I and II in cutaneous wounds of diabetic and nondiabetic mice. Am. J. Pathol., 1997, 151, 715-24.

[75] Teixeira, A.S.; Andrade, S.P. Glucose-induced inhibition of angiogenesis in the rat sponge granuloma is prevented by aminoguanidine. Life Sci., 1999, 64, 655-62.

[76] Frank, S.; Hubner, G.; Breier, G.; Longaker, M.T.; Greenhalgh, D.G.; Werner, S. Regulation of vascular endothelial growth factor expression in cultured keratinocytes. Implications for normal and impaired wound healing. J. Biol. Chem., 1995, 270, 12607-13.

[77] Altavilla, D.; Saitta, A.; Cucinotta, D.; Galeano, M.; Deodato, B.; Colonna, M.; Torre, V.; Russo, G.; Sardella, A.; Urna, G.; Campo, G.M., Cavallari, V.; Squadrito, G.; Squadrito, F. Inhibition of lipid peroxidation restores impaired vascular endothelial growth factor expression and stimulates wound healing and angiogenesis in the genetically diabetic mouse. Diabetes, 2001, 50, 667-74.

[78] Goova, M.T.; Li, J.; Kislinger, T.; Qu, W.; Lu, Y.; Bucciarelli, L.G.; Nowygrod, S.; Wolf, B.M.; Caliste, X.; Yan, S.F.; Stern, D.M.; Schmidt, A.M. Blockade of receptor for advanced glycation end-products restores effective wound healing in diabetic mice. Am. J. Pathol., 2001, 159, 513-25.

[79] Corral, C.J.; Siddiqui, A.; Wu, L.; Farrell, C.L.; Lyons, D.; Mustoe, T.A. Vascular endothelial growth factor is more important than basic fibroblastic growth factor during ischemic wound healing. Arch. Surg., 1999, 134, 200-5.

[80] Howdieshell, T.R.; Callaway, D.; Webb, W.L.; Gaines, M.D.; Procter, C.D. Jr.; Sathyanarayana; Pollock, J.S.; Brock, T.L.; McNeil, P.L. Antibody neutralization of vascular endothelial growth factor inhibits wound granulation tissue formation. J. Surg. Res., 2001, 96, 173-82.

[81] Lerman, O.Z.; Galiano, R.D.; Armour, M.; Levine, J.P.; Gurtner, G.C. Cellular dysfunction in the diabetic fibroblast: impairment in migration, vascular endothelial growth factor production, and response to hypoxia. Am. J. Pathol., 2003, 162, 303-12.
[82] Galiano, R.D.; Tepper, O.M.; Pelo, C.R.; Bhatt, K.A.; Callaghan, M.; Bastidas, N.; Bunting, S.; Steinmetz, H.G.; Gurtner, G.C. Topical vascular endothelial growth factor accelerates diabetic wound healing through increased angiogenesis and by mobilizing and recruiting bone marrow-derived cells. Am. J. Pathol., 2004, 164 $1935-47$

[83] Asahara, T.; Murohara, T.; Sullivan, A.; Silver, M.; van der Zee, R.; Li, T.; Witzenbichler, B.; Schatteman, G.; Isner, J.M. Isolation of putative progenitor endothelial cells for angiogenesis. Science, 1997, 275, 964-7.

[84] Gill, M.; Dias, S.; Hattori, K.; Rivera, M.L.; Hicklin, D.; Witte, L.; Girardi, L.; Yurt, R.; Himel, H.; Rafii, S. Vascular trauma induces rapid but transient mobilization of VEGFR2(+)AC133(+) endothelial precursor cells. Circ. Res., 2001, 88, 167-74.

[85] Peichev, M.; Naiyer, A.J.; Pereira, D.; Zhu, Z.; Lane, W.J.; Williams, M.; Oz, M.C.; Hicklin, D.J.; Witte, L.; Moore, M.A.; Rafii, $\mathrm{S}$. Expression of VEGFR-2 and AC133 by circulating human CD34(+) cells identifies a population of functional endothelial precursors. Blood, 2000, 95, 952-8.

[86] Fadini, G.P.; Miorin, M.; Facco, M.; Bonamico, S.; Baesso, I.; Grego, F.; Menegolo, M.; de Kreutzenberg, S.V.; Tiengo, A.; Agostini, C.; Avogaro, A. Circulating endothelial progenitor cells are reduced in peripheral vascular complications of type 2 diabetes mellitus. J. Am. Coll. Cardiol., 2005, 45, 1449-57.

[87] Keswani, S.G.; Katz, A.B.; Lim, F.Y.; Zoltick, P.; Radu, A.; Alaee, D.; Herlyn, M.; Crombleholme, T.M. Adenoviral mediated gene transfer of PDGF-B enhances wound healing in type I and type II diabetic wounds. Wound Repair Regen., 2004, 12, 497-504

[88] Loomans, C.J.; De Koning, E.J.; Staal, F.J.; Rabelink, T.J.; Zonneveld, A.J. Endothelial progenitor cell dysfunction in type 1 diabetes: another consequence of oxidative stress? Antioxid. Redox Signal, 2005, 7, 1468-75.

[89] Loomans, C.J.; de Koning, E.J.; Staal, F.J.; Rookmaaker, M.B.; Verseyden, C.; de Boer, H.C.; Verhaar, M.C.; Braam, B.; Rabelink, T.J.; van Zonneveld, A.J. Endothelial progenitor cell dysfunction: a novel concept in the pathogenesis of vascular complications of type 1 diabetes. Diabetes, 2004, 53, 195-9.

[90] Tepper, O.M.; Galiano, R.D.; Capla, J.M.; Kalka, C.; Gagne, P.J.; Jacobowitz, G.R.; Levine, J.P.; Gurtner, G.C. Human endothelial progenitor cells from type II diabetics exhibit impaired proliferation, adhesion, and incorporation into vascular structures. Circulation, 2002, 106, 2781-6.

[91] Vasa, M.; Fichtlscherer, S.; Aicher, A.; Adler, K.; Urbich, C.; Martin, H.; Zeiher, A.M.; Dimmeler, S. Number and migratory activity of circulating endothelial progenitor cells inversely correlate with risk factors for coronary artery disease. Circ. Res., 2001, 89, E1-7.

[92] Ii, M.; Takenaka, H.; Asai, J.; Ibusuki, K.; Mizukami, Y.; Maruyama, K.; Yoon, Y.S.; Wecker, A.; Luedemann, C.; Eaton, E.; Silver, M.; Thorne, T.; Losordo, D.W. Endothelial progenitor thrombospondin-1 mediates diabetes-induced delay in reendothelialization following arterial injury. Circ. Res., 2006, 98, 697-704.

[93] Kawachi, Y.; Watanabe, A.; Uchida, T.; Yoshizawa, K.; Kurooka, N.; Setsu, K. Acute arterial thrombosis due to platelet aggregation in a patient receiving granulocyte colony-stimulating factor. $\mathrm{Br} . \mathrm{J}$. Haematol., 1996, 94, 413-6.

[94] Li, B.; Ogasawara, A.K.; Yang, R.; Wei, W.; He, G.W.; Zioncheck, T.F.; Bunting, S.; de Vos, A.M.; Jin, H. KDR (VEGF receptor 2) is the major mediator for the hypotensive effect of VEGF. Hypertension, 2002, 39, 1095-100.

[95] Fukumoto, Y.; Miyamoto, T.; Okamura, T.; Gondo, H.; Iwasaki, H.; Horiuchi, T.; Yoshizawa, S.; Inaba, S.; Harada, M.; Niho, Y. Angina pectoris occurring during granulocyte colony-stimulating factor-combined preparatory regimen for autologous peripheral blood stem cell transplantation in a patient with acute myelogenous leukaemia. Br. J. Haematol., 1997, 97, 666-8.

[96] Lindemann, A.; Rumberger, B. Vascular complications in patients treated with granulocyte colony-stimulating factor (G-CSF). Eur. J. Cancer, 1993, 29A, 2338-9.

[97] Potter, C.F.; Kuo, N.T.; Farver, C.F.; McMahon, J.T.; Chang, C.H.; Agani, F.H.; Haxhiu, M.A.; Martin, R.J. Effects of hyperoxia on nitric oxide synthase expression, nitric oxide activity, and lung injury in rat pups. Pediatr. Res., 1999, 45, 8-13.

[98] Roosterman, D.; Goerge, T.; Schneider, S.W.; Bunnett, N.W.; Steinhoff, M. Neuronal control of skin function: the skin as a neuroimmunoendocrine organ. Physiol. Rev., 2006, 86, 1309-79. 
[99] Delgado, A.V.; McManus, A.T.; Chambers, J.P. Exogenous administration of Substance $P$ enhances wound healing in a novel skin-injury model. Exp. Biol. Med., 2005, 230, 271-80.

[100] Ekstrand, A.J.; Cao, R.; Bjorndahl, M.; Nystrom, S.; JonssonRylander, A.C.; Hassani, H.; Hallberg, B.; Nordlander, M.; Cao, Y. Deletion of neuropeptide Y (NPY) 2 receptor in mice results in blockage of NPY-induced angiogenesis and delayed wound healing. Proc. Natl. Acad. Sci. U. S. A., 2003, 100, 6033-8.

[101] Toda, M.; Suzuki, T.; Hosono, K.; Kurihara, Y.; Kurihara, H.; Hayashi, I.; Kitasato, H.; Hoka, S.; Majima, M. Roles of calcitonin gene-related peptide in facilitation of wound healing and angiogenesis. Biomed. Pharmacother., 2008, 62, 352-9.

[102] Pernow, B. Substance P. Pharmacol. Rev., 1983, 35, 85-141.

[103] Barber, R.P.; Vaughn, J.E.; Slemmon, J.R.; Salvaterra, P.M.; Roberts, E.; Leeman, S.E. The origin, distribution and synaptic relationships of substance P axons in rat spinal cord. J. Comp. Neurol., 1979, 184, 331-51.

[104] Harrison, S.; Geppetti, P. Substance p. Int. J. Biochem. Cell Biol., 2001, 33, 555-76.

[105] Khawaja, A.M.; Rogers, D.F. Tachykinins: receptor to effector. Int. J. Biochem. Cell Biol., 1996, 28, 721-38.

[106] Krause, J.E.; Takeda, Y.; Hershey, A.D. Structure, functions, and mechanisms of substance P receptor action. J. Invest. Dermatol., 1992, 98, 2S-7S.

[107] Kunt, T.; Forst, T.; Schmidt, S.; Pfutzner, A.; Schneider, S.; Harzer, O.; Lobig, M.; Engelbach, M.; Goitom, K.; Pohlmann, T.; Beyer, J. Serum levels of substance $\mathrm{P}$ are decreased in patients with type 1 diabetes. Exp. Clin. Endocrinol. Diabetes, 2000, 108, 164-7.

[108] Lindberger, M.; Schroder, H.D.; Schultzberg, M.; Kristensson, K.; Persson, A.; Ostman, J.; Link, H. Nerve fibre studies in skin biopsies in peripheral neuropathies. I. Immunohistochemical analysis of neuropeptides in diabetes mellitus. J. Neurol. Sci., 1989, 93, 28996.

[109] Gibran, N.S.; Jang, Y.C.; Isik, F.F.; Greenhalgh, D.G.; Muffley, L.A.; Underwood, R.A.; Usui, M.L.; Larsen, J.; Smith, D.G.; Bunnett, N.; Ansel, J.C.; Olerud, J.E. Diminished neuropeptide levels contribute to the impaired cutaneous healing response associated with diabetes mellitus. J. Surg. Res., 2002, 108, 122-8.

[110] Antezana, M.; Sullivan, S.R.; Usui, M.; Gibran, N.; Spenny, M.; Larsen, J.; Ansel, J.; Bunnett, N.; Olerud, J. Neutral endopeptidase activity is increased in the skin of subjects with diabetic ulcers. $J$. Invest. Dermatol., 2002, 119, 1400-4.

[111] Spenny, M.L.; Muangman, P.; Sullivan, S.R.; Bunnett, N.W.; Ansel, J.C.; Olerud, J.E.; Gibran, N.S. Neutral endopeptidase inhibition in diabetic wound repair. Wound Repair Regen., 2002, 10, 295-301.

[112] Bolton, T.B.; Clapp, L.H. Endothelial-dependent relaxant actions of carbachol and substance $\mathrm{P}$ in arterial smooth muscle. Br. $J$. Pharmacol., 1986, 87, 713-23.

[113] Hokfelt, T.; Kellerth, J.O.; Nilsson, G.; Pernow, B. Experimental immunohistochemical studies on the localization and distribution of substance P in cat primary sensory neurons. Brain Res., 1975, 100, 235-52.

[114] Devillier, P.; Regoli, D.; Asseraf, A.; Descours, B.; Marsac, J.; Renoux, M. Histamine release and local responses of rat and human skin to substance $\mathrm{P}$ and other mammalian tachykinins. Pharmacology, 1986, 32, 340-7.

[115] Lundberg, J.M.; Saria, A.; Brodin, E.; Rosell, S.; Folkers, K. A substance $\mathrm{P}$ antagonist inhibits vagally induced increase in vascular permeability and bronchial smooth muscle contraction in the guinea pig. Proc. Natl. Acad. Sci. U. S. A., 1983, 80, 1120-4.

[116] Delgado, A.V.; McManus, A.T.; Chambers, J.P. Production of tumor necrosis factor-alpha, interleukin 1-beta, interleukin 2 , and interleukin 6 by rat leukocyte subpopulations after exposure to substance P. Neuropeptides, 2003, 37, 355-61.

[117] Wiedermann, C.J.; Auer, B.; Sitte, B.; Reinisch, N.; Schratzberger, P.; Kahler, C.M. Induction of endothelial cell differentiation into capillary-like structures by substance P. Eur. J. Pharmacol., 1996, 298, 335-8.

[118] Carolan, E.J.; Casale, T.B. Effects of neuropeptides on neutrophil migration through noncellular and endothelial barriers. J. Allergy Clin. Immunol., 1993, 92, 589-98.

[119] Matis, W.L.; Lavker, R.M.; Murphy, G.F. Substance P induces the expression of an endothelial-leukocyte adhesion molecule by microvascular endothelium. J. Invest. Dermatol., 1990, 94, 492-5.
[120] Quinlan, K.L.; Naik, S.M.; Cannon, G.; Armstrong, C.A.; Bunnett, N.W.; Ansel, J.C.; Caughman, S.W. Substance P activates coincident NF-AT- and NF-kappa B-dependent adhesion molecule gene expression in microvascular endothelial cells through intracellular calcium mobilization. J. Immunol., 1999, 163, 5656-65.

[121] Quinlan, K.L.; Song, I.S.; Bunnett, N.W.; Letran, E.; Steinhoff, M.; Harten, B.; Olerud, J.E.; Armstrong, C.A.; Wright Caughman, S.; Ansel, J.C. Neuropeptide regulation of human dermal microvascular endothelial cell ICAM-1 expression and function. Am. J. Physiol., 1998, 275, C1580-90.

[122] Roch-Arveiller, M.; Regoli, D.; Chanaud, B.; Lenoir, M.; Muntaner, O.; Stralzko, S.; Giroud, J.P. Tachykinins: effects on motility and metabolism of rat polymorphonuclear leucocytes. Pharmacology, 1986, 33, 266-73.

[123] Vishwanath, R.; Mukherjee, R. Substance P promotes lymphocyteendothelial cell adhesion preferentially via LFA-1/ICAM-1 interactions. J. Neuroimmunol., 1996, 71, 163-71.

[124] Benrath, J.; Zimmermann, M.; Gillardon, F. Substance P and nitric oxide mediate would healing of ultraviolet photodamaged rat skin: evidence for an effect of nitric oxide on keratinocyte proliferation. Neurosci. Lett., 1995, 200, 17-20.

[125] Burssens, P.; Steyaert, A.; Forsyth, R.; van Ovost, E.J.; Depaepe, Y.; Verdonk, R. Exogenously administered substance P and neutral endopeptidase inhibitors stimulate fibroblast proliferation, angiogenesis and collagen organization during Achilles tendon healing. Foot Ankle Int., 2005, 26, 832-9.

[126] Wang, Q.; Muffley, L.A.; Hall, K.; Chase, M.; Gibran, N.S. Elevated glucose and fatty acid levels impair substance $\mathrm{P}$ induced dermal microvascular endothelial cell migration and proliferation in an agarose gel model system. Shock, 2009, 32, 491-7.

[127] Tatemoto, K.; Carlquist, M.; Mutt, V. Neuropeptide Y--a novel brain peptide with structural similarities to peptide YY and pancreatic polypeptide. Nature, 1982, 296, 659-60.

[128] Blomqvist, A.G.; Herzog, H. Y-receptor subtypes--how many more? Trends Neurosci., 1997, 20, 294-8.

[129] Bracci-Laudiero, L.; Aloe, L.; Stenfors, C.; Tirassa, P.; Theodorsson, E.; Lundberg, T. Nerve growth factor stimulates production of neuropeptide Y in human lymphocytes. Neuroreport, 1996, 7, 4858.

[130] Alvaro, A.R.; Rosmaninho-Salgado, J.; Santiago, A.R.; Martins, J.; Aveleira, C.; Santos, P.F.; Pereira, T.; Gouveia, D.; Carvalho, A.L.; Grouzmann, E.; Ambrosio, A.F.; Cavadas, C. NPY in rat retina is present in neurons, in endothelial cells and also in microglial and Muller cells. Neurochem. Int., 2007, 50, 757-63.

[131] Cai, W.Q.; Bodin, P.; Sexton, A.; Loesch, A.; Burnstock, G. Localization of neuropeptide $\mathrm{Y}$ and atrial natriuretic peptide in the endothelial cells of human umbilical blood vessels. Cell. Tissue. Res., 1993, 272, 175-81.

[132] Jacques, D.; Sader, S.; Perreault, C.; Abdel-Samad, D.; Jules, F.; Provost, C. NPY, ET-1, and Ang II nuclear receptors in human endocardial endothelial cells. Can. J. Physiol. Pharmacol., 2006, 84, 299-307.

[133] Schwarz, H.; Villiger, P.M.; von Kempis, J.; Lotz, M. Neuropeptide $\mathrm{Y}$ is an inducible gene in the human immune system. J. Neuroimmunol., 1994, 51, 53-61.

[134] Silva, A.P.; Kaufmann, J.E.; Vivancos, C.; Fakan, S.; Cavadas, C.; Shaw, P.; Brunner, H.R.; Vischer, U.; Grouzmann, E. Neuropeptide $\mathrm{Y}$ expression, localization and cellular transducing effects in $\mathrm{HU}$ VEC. Biol. Cell., 2005, 97, 457-67.

[135] Larhammar, D. Structural diversity of receptors for neuropeptide Y, peptide YY and pancreatic polypeptide. Regul. Pept., 1996, 65, 165-74.

[136] Wahlestedt, C.; Hakanson, R.; Vaz, C.A.; Zukowska-Grojec, Z. Norepinephrine and neuropeptide $\mathrm{Y}$ : vasoconstrictor cooperation in vivo and in vitro. Am. J. Physiol., 1990, 258, R736-42.

[137] Wheway, J.; Mackay, C.R.; Newton, R.A.; Sainsbury, A.; Boey, D.; Herzog, H.; Mackay, F. A fundamental bimodal role for neuropeptide Y1 receptor in the immune system. J. Exp. Med., 2005 , 202, 1527-38.

[138] Pons, J.; Kitlinska, J.; Ji, H.; Lee, E.W.; Zukowska, Z. Mitogenic actions of neuropeptide $\mathrm{Y}$ in vascular smooth muscle cells: synergetic interactions with the beta-adrenergic system. Can. J. Physiol. Pharmacol., 2003, 81, 177-85.

[139] Frankish, H.M.; Dryden, S.; Hopkins, D.; Wang, Q.; Williams, G. Neuropeptide Y, the hypothalamus, and diabetes: insights into the central control of metabolism. Peptides, 1995, 16, 757-71. 
[140] Ahlborg, G.; Lundberg, J.M. Exercise-induced changes in neuropeptide $\mathrm{Y}$, noradrenaline and endothelin-1 levels in young people with type I diabetes. Clin. Physiol., 1996, 16, 645-55.

[141] Levy, D.M.; Karanth, S.S.; Springall, D.R.; Polak, J.M. Depletion of cutaneous nerves and neuropeptides in diabetes mellitus: an immunocytochemical study. Diabetologia, 1989, 32, 427-33.

[142] Wallengren, J.; Badendick, K.; Sundler, F.; Hakanson, R.; Zander, E. Innervation of the skin of the forearm in diabetic patients: relation to nerve function. Acta. Derm. Venereol., 1995, 75, 37-42.

[143] Kuncova, J.; Sviglerova, J.; Tonar, Z.; Slavikova, J. Heterogenous changes in neuropeptide $\mathrm{Y}$, norepinephrine and epinephrine concentrations in the hearts of diabetic rats. Auton. Neurosci., 2005, 121, 7-15.

[144] Andersson, D.; Brunkwall, J.; Bergqvist, D.; Edvinsson, L. Diminished contractile responses to neuropeptide $\mathrm{Y}$ of arteries from diabetic rabbits. J. Auton. Nerv. Syst., 1992, 37, 215-22.

[145] Wheway, J.; Herzog, H.; Mackay, F. NPY and receptors in immune and inflammatory diseases. Curr. Top. Med. Chem., 2007, 7, 174352.

[146] Ghersi, G.; Chen, W.; Lee, E.W.; Zukowska, Z. Critical role of dipeptidyl peptidase IV in neuropeptide Y-mediated endothelial cell migration in response to wounding. Peptides, 2001, 22, 453-8.

[147] Marion-Audibert, A.M.; Nejjari, M.; Pourreyron, C.; Anderson, W.; Gouysse, G.; Jacquier, M.F.; Dumortier, J.; Scoazec, J.Y. Effects of endocrine peptides on proliferation, migration and differentiation of human endothelial cells. Gastroenterol. Clin. Biol., 2000, 24, 644-8.

[148] Kitlinska, J.; Lee, E.W.; Movafagh, S.; Pons, J.; Zukowska, Z. Neuropeptide Y-induced angiogenesis in aging. Peptides, 2002, 23, 71-7.

[149] van Rossum, D.; Hanisch, U.K.; Quirion, R. Neuroanatomical localization, pharmacological characterization and functions of CGRP, related peptides and their receptors. Neurosci. Biobehav. Rev., 1997, 21, 649-78.

[150] Holzer, P. Local effector functions of capsaicin-sensitive sensory nerve endings: involvement of tachykinins, calcitonin gene-related peptide and other neuropeptides. Neuroscience, 1988, 24, 739-68.

[151] Maggi, C.A. Tachykinins and calcitonin gene-related peptide (CGRP) as co-transmitters released from peripheral endings of sensory nerves. Prog. Neurobiol., 1995, 45, 1-98.

[152] Hay, D.L.; Poyner, D.R.; Quirion, R. International Union of Pharmacology. LXIX. Status of the calcitonin gene-related peptide subtype 2 receptor. Pharmacol. Rev., 2008, 60, 143-5.

[153] Brain, S.D.; Williams, T.J.; Tippins, J.R.; Morris, H.R.; MacIntyre, I. Calcitonin gene-related peptide is a potent vasodilator. Nature, 1985, 313, 54-6.

[154] Gamse, R.; Saria, A. Potentiation of tachykinin-induced plasma protein extravasation by calcitonin gene-related peptide. Eur. J. Pharmacol., 1985, 114, 61-6.

[155] Louis, S.M.; Jamieson, A.; Russell, N.J.; Dockray, G.J. The role of substance $\mathrm{P}$ and calcitonin gene-related peptide in neurogenic plasma extravasation and vasodilatation in the rat. Neuroscience, 1989, 32, 581-6.

[156] Adeghate, E.; Rashed, H.; Rajbandari, S.; Singh, J. Pattern of distribution of calcitonin gene-related Peptide in the dorsal root ganglion of animal models of diabetes mellitus. Ann. N. Y. Acad. Sci., 2006, 1084, 296-303.

[157] Jiang, Y.; Nyengaard, J.R.; Zhang, J.S.; Jakobsen, J. Selective loss of calcitonin gene-related Peptide-expressing primary sensory neurons of the a-cell phenotype in early experimental diabetes. Diabetes, 2004, 53, 2669-75.

[158] Song, J.X.; Wang, L.H.; Yao, L.; Xu, C.; Wei, Z.H.; Zheng, L.R. Impaired transient receptor potential vanilloid 1 in streptozotocininduced diabetic hearts. Int. J. Cardiol., 2009, 134, 290-2.

[159] Chottova Dvorakova, M.; Kuncova, J.; Pfeil, U.; McGregor, G.P.; Sviglerova, J.; Slavikova, J.; Kummer, W. Cardiomyopathy in streptozotocin-induced diabetes involves intra-axonal accumulation of calcitonin gene-related peptide and altered expression of its receptor in rats. Neuroscience, 2005, 134, 51-8.

[160] Yorek, M.A.; Coppey, L.J.; Gellett, J.S.; Davidson, E.P. Sensory nerve innervation of epineurial arterioles of the sciatic nerve containing calcitonin gene-related peptide: effect of streptozotocininduced diabetes. Exp. Diabesity. Res., 2004, 5, 187-93.

[161] Oltman, C.L.; Davidson, E.P.; Coppey, L.J.; Kleinschmidt, T.L.; Lund, D.D.; Adebara, E.T.; Yorek, M.A. Vascular and neural dys- function in Zucker diabetic fatty rats: a difficult condition to reverse. Diabetes. Obes. Metab., 2008, 10, 64-74.

[162] Oltman, C.L.; Davidson, E.P.; Coppey, L.J.; Kleinschmidt, T.L.; Yorek, M.A. Treatment of Zucker diabetic fatty rats with AVE7688 improves vascular and neural dysfunction. Diabetes Obes. Metab., 2009, 11, 223-33.

[163] Sheykhzade, M.; Dalsgaard, G.T.; Johansen, T.; Nyborg, N.C. The effect of long-term streptozotocin-induced diabetes on contractile and relaxation responses of coronary arteries: selective attenuation of CGRP-induced relaxations. Br. J. Pharmacol., 2000, 129, 1212 8.

[164] Haegerstrand, A.; Dalsgaard, C.J.; Jonzon, B.; Larsson, O.; Nilsson, J. Calcitonin gene-related peptide stimulates proliferation of human endothelial cells. Proc. Natl. Acad. Sci. U. S. A., 1990, 87, 3299-303.

[165] Ambalavanar, R.; Dessem, D.; Moutanni, A.; Yallampalli, C. Yallampalli, U.; Gangula, P.; Bai, G. Muscle inflammation induces a rapid increase in calcitonin gene-related peptide (CGRP) mRNA that temporally relates to CGRP immunoreactivity and nociceptive behavior. Neuroscience, 2006, 143, 875-84.

[166] Ambalavanar, R.; Moritani, M.; Moutanni, A.; Gangula, P.; Yallampalli, C.; Dessem, D. Deep tissue inflammation upregulates neuropeptides and evokes nociceptive behaviors which are modulated by a neuropeptide antagonist. Pain, 2006, 120, 53-68.

[167] Sung, C.P.; Arleth, A.J.; Aiyar, N.; Bhatnagar, P.K.; Lysko, P.G.; Feuerstein, G. CGRP stimulates the adhesion of leukocytes to vascular endothelial cells. Peptides, 1992, 13, 429-34.

[168] Buckley, T.L.; Brain, S.D.; Jose, P.J.; Williams, T.J. The partial inhibition of inflammatory responses induced by capsaicin using the Fab fragment of a selective calcitonin gene-related peptide antiserum in rabbit skin. Neuroscience, 1992, 48, 963-8.

[169] Luger, T.A. Neuromediators--a crucial component of the skin immune system. J. Dermatol. Sci., 2002, 30, 87-93.

[170] Dallos, A.; Kiss, M.; Polyanka, H.; Dobozy, A.; Kemeny, L.; Husz, $\mathrm{S}$. Effects of the neuropeptides substance $\mathrm{P}$, calcitonin gene-related peptide, vasoactive intestinal polypeptide and galanin on the production of nerve growth factor and inflammatory cytokines in cultured human keratinocytes. Neuropeptides, 2006, 40, 251-63.

[171] Wang, F.; Millet, I.; Bottomly, K.; Vignery, A. Calcitonin generelated peptide inhibits interleukin 2 production by murine $\mathrm{T}$ lymphocytes. J. Biol. Chem., 1992, 267, 21052-7.

[172] Yamaguchi, M.; Kojima, T.; Kanekawa, M.; Aihara, N.; Nogimura, A.; Kasai, K. Neuropeptides stimulate production of interleukin-1 beta, interleukin-6, and tumor necrosis factor-alpha in human dental pulp cells. Inflamm. Res., 2004, 53, 199-204.

[173] Yaraee, R.; Ebtekar, M.; Ahmadiani, A.; Sabahi, F. Neuropeptides (SP and CGRP) augment pro-inflammatory cytokine production in HSV-infected macrophages. Int. Immunopharmacol., 2003, 3, 1883-7.

[174] Hara, M.; Toyoda, M.; Yaar, M.; Bhawan, J.; Avila, E.M.; Penner, I.R.; Gilchrest, B.A. Innervation of melanocytes in human skin. $J$. Exp. Med., 1996, 184, 1385-95.

[175] Toyoda, M.; Luo, Y.; Makino, T.; Matsui, C.; Morohashi, M. Calcitonin gene-related peptide upregulates melanogenesis and enhances melanocyte dendricity via induction of keratinocyte-derived melanotrophic factors. J. Investig. Dermatol. Symp. Proc., 1999, 4, 116-25.

[176] Pradhan, L.; Nabzdyk, C.; Andersen, N.D.; LoGerfo, F.W.; Veves, A. Inflammation and neuropeptides: the connection in diabetic wound healing. Expert. Rev. Mol. Med., 2009, 11, e2.

[177] Ishihara, M.; Fujita, M.; Obara, K.; Hattori, H.; Nakamura, S. Nambu, M.; Kiyosawa, T.; Kanatani, Y.; Takase, B.; Kikuchi, M.; Maehara, T. Controlled releases of FGF-2 and paclitaxel from chitosan hydrogels and their subsequent effects on wound repair, angiogenesis, and tumor growth. Curr. Drug. Deliv., 2006, 3, 351-8.

[178] Kawai, K.; Suzuki, S.; Tabata, Y.; Nishimura, Y. Accelerated wound healing through the incorporation of basic fibroblast growth factor-impregnated gelatin microspheres into artificial dermis using a pressure-induced decubitus ulcer model in genetically diabetic mice. Br. J. Plast. Surg., 2005, 58, 1115-23.

[179] Obara, K.; Ishihara, M.; Fujita, M.; Kanatani, Y.; Hattori, H.; Matsui, T.; Takase, B.; Ozeki, Y.; Nakamura, S.; Ishizuka, T.; Tominaga, S.; Hiroi, S.; Kawai, T.; Maehara, T. Acceleration of wound healing in healing-impaired $\mathrm{db} / \mathrm{db}$ mice with a photocrosslinkable chitosan hydrogel containing fibroblast growth factor-2. Wound. Repair. Regen., 2005, 13, 390-7. 
[180] Cruciani, M.; Lipsky, B.A.; Mengoli, C.; de Lalla, F. Are granulocyte colony-stimulating factors beneficial in treating diabetic foot infections? A meta-analysis. Diabetes Care, 2005, 28, 454-60.

[181] Huang, P.; Li, S.; Han, M.; Xiao, Z.; Yang, R.; Han, Z.C. Autologous transplantation of granulocyte colony-stimulating factormobilized peripheral blood mononuclear cells improves critical limb ischemia in diabetes. Diabetes Care, 2005, 28, 2155-60.

[182] Kastenbauer, T.; Hornlein, B.; Sokol, G.; Irsigler, K. Evaluation of granulocyte-colony stimulating factor (Filgrastim) in infected diabetic foot ulcers. Diabetologia, 2003, 46, 27-30.

[183] Bevan, D.; Gherardi, E.; Fan, T.P.; Edwards, D.; Warn, R. Diverse and potent activities of $\mathrm{HGF} / \mathrm{SF}$ in skin wound repair. J. Pathol., 2004, 203, 831-8.

[184] Morishita, R.; Aoki, M.; Hashiya, N.; Makino, H.; Yamasaki, K.; Azuma, J.; Sawa, Y.; Matsuda, H.; Kaneda, Y.; Ogihara, T. Safety evaluation of clinical gene therapy using hepatocyte growth factor to treat peripheral arterial disease. Hypertension, 2004, 44, 203-9.

[185] Nayeri, F.; Stromberg, T.; Larsson, M.; Brudin, L.; Soderstrom, C.; Forsberg, P. Hepatocyte growth factor may accelerate healing in chronic leg ulcers: a pilot study. J. Dermatolog. Treat., 2002, 13, 81-6.

[186] Powell, R.J.; Dormandy, J.; Simons, M.; Morishita, R.; Annex, B.H. Therapeutic angiogenesis for critical limb ischemia: design of the hepatocyte growth factor therapeutic angiogenesis clinical trial. Vasc. Med., 2004, 9, 193-8.

[187] Yoshida, S.; Matsumoto, K.; Tomioka, D.; Bessho, K.; Itami, S.; Yoshikawa, K.; Nakamura, T. Recombinant hepatocyte growth factor accelerates cutaneous wound healing in a diabetic mouse model. Growth Factors, 2004, 22, 111-9.

[188] Howell, T.H.; Fiorellini, J.P.; Paquette, D.W.; Offenbacher, S.; Giannobile, W.V.; Lynch, S.E. A phase I/II clinical trial to evaluate a combination of recombinant human platelet-derived growth factor-BB and recombinant human insulin-like growth factor-I in patients with periodontal disease. J. Periodontol., 1997, 68, 1186-93.

[189] Nagai, M.K.; Embil, J.M. Becaplermin: recombinant platelet derived growth factor, a new treatment for healing diabetic foot ulcers. Expert Opin. Biol. Ther., 2002, 2, 211-8.

[190] Chen, R.R.; Mooney, D.J. Polymeric growth factor delivery strategies for tissue engineering. Pharm. Res., 2003, 20, 1103-12.

[191] Liechty, K.W.; Nesbit, M.; Herlyn, M.; Radu, A.; Adzick, N.S.; Crombleholme, T.M. Adenoviral-mediated overexpression of platelet-derived growth factor-B corrects ischemic impaired wound healing. J. Invest. Dermatol., 1999, 113, 375-83.

[192] Khavari, P.A.; Rollman, O.; Vahlquist, A. Cutaneous gene transfer for skin and systemic diseases. J. Intern. Med., 2002, 252, 1-10.

[193] Cohen, H.; Levy, R.J.; Gao, J.; Fishbein, I.; Kousaev, V.; Sosnowski, S.; Slomkowski, S.; Golomb, G. Sustained delivery and expression of DNA encapsulated in polymeric nanoparticles. Gene. Ther., 2000, 7, 1896-905.

[194] Shea, L.D.; Smiley, E.; Bonadio, J.; Mooney, D.J. DNA delivery from polymer matrices for tissue engineering. Nat. Biotechnol., 1999, 17, 551-4.

[195] Lee, J.A.; Conejero, J.A.; Mason, J.M.; Parrett, B.M.; WearMaggitti, K.D.; Grant, R.T.; Breitbart, A.S. Lentiviral transfection with the PDGF-B gene improves diabetic wound healing. Plast. Reconstr. Surg., 2005, 116, 532-8.

[196] Bitto, A.; Minutoli, L.; Galeano, M.R.; Altavilla, D.; Polito, F.; Fiumara, T.; Calo, M.; Lo Cascio, P.; Zentilin, L.; Giacca, M.; Squadrito, F. Angiopoietin-1 gene transfer improves impaired wound healing in genetically diabetic mice without increasing VEGF expression. Clin. Sci. (Lond), 2008, 114, 707-18.
[197] Badillo, A.T.; Chung, S.; Zhang, L.; Zoltick, P.; Liechty, K.W. Lentiviral gene transfer of SDF-1alpha to wounds improves diabetic wound healing. J. Surg. Res., 2007, 143, 35-42.

[198] Breen, A.M.; Dockery, P.; O'Brien, T.; Pandit, A.S. The use of therapeutic gene eNOS delivered via a fibrin scaffold enhances wound healing in a compromised wound model. Biomaterials, 2008, 29, 3143-51.

[199] Baker, L.L.; Chambers, R.; DeMuth, S.K.; Villar, F. Effects of electrical stimulation on wound healing in patients with diabetic ulcers. Diabetes Care, 1997, 20, 405-12.

[200] Lee, P.Y.; Chesnoy, S.; Huang, L. Electroporatic delivery of TGFbeta1 gene works synergistically with electric therapy to enhance diabetic wound healing in $\mathrm{db} / \mathrm{db}$ mice. J. Invest. Dermatol., 2004 123, 791-8.

[201] Marti, G.; Ferguson, M.; Wang, J.; Byrnes, C.; Dieb, R.; Qaiser, R.; Bonde, P.; Duncan, M.D.; Harmon, J.W. Electroporative transfection with KGF-1 DNA improves wound healing in a diabetic mouse model. Gene. Ther., 2004, 11, 1780-5.

[202] Marston, W.A.; Hanft, J.; Norwood, P.; Pollak, R. The efficacy and safety of Dermagraft in improving the healing of chronic diabetic foot ulcers: results of a prospective randomized trial. Diabetes Care, 2003, 26, 1701-5.

[203] Brem, H.; Balledux, J.; Bloom, T.; Kerstein, M.D.; Hollier, L. Healing of diabetic foot ulcers and pressure ulcers with human skin equivalent: a new paradigm in wound healing. Arch. Surg., 2000, 135, 627-34.

[204] Krause, D.S.; Theise, N.D.; Collector, M.I.; Henegariu, O.; Hwang, S.; Gardner, R.; Neutzel, S.; Sharkis, S.J. Multi-organ, multilineage engraftment by a single bone marrow-derived stem cell Cell, 2001, 105, 369-77.

[205] Nakagawa, H.; Akita, S.; Fukui, M.; Fujii, T.; Akino, K. Human mesenchymal stem cells successfully improve skin-substitute wound healing. Br. J. Dermatol., 2005, 153, 29-36.

[206] Wu, Y.; Chen, L.; Scott, P.G.; Tredget, E.E. Mesenchymal stem cells enhance wound healing through differentiation and angiogenesis. Stem Cells, 2007, 25, 2648-59.

[207] Sivan-Loukianova, E.; Awad, O.A.; Stepanovic, V.; Bickenbach, J.; Schatteman, G.C. CD34+ blood cells accelerate vascularization and healing of diabetic mouse skin wounds. J. Vasc. Res., 2003, 40, 368-77.

[208] Capla, J.M.; Grogan, R.H.; Callaghan, M.J.; Galiano, R.D.; Tepper, O.M.; Ceradini, D.J.; Gurtner, G.C. Diabetes impairs endothelial progenitor cell-mediated blood vessel formation in response to hypoxia. Plast. Reconstr. Surg., 2007, 119, 59-70.

[209] Shepherd, A.J.; Downing, J.E.; Miyan, J.A. Without nerves, immunology remains incomplete -in vivo veritas. Immunology, 2005, $116,145-63$.

[210] Steinhoff, M.; Stander, S.; Seeliger, S.; Ansel, J.C.; Schmelz, M.; Luger, T. Modern aspects of cutaneous neurogenic inflammation. Arch. Dermatol., 2003, 139, 1479-88.

[211] Nakamura, M.; Kawahara, M.; Morishige, N.; Chikama, T.; Nakata, K.; Nishida, T. Promotion of corneal epithelial wound healing in diabetic rats by the combination of a substance P-derived peptide (FGLM-NH2) and insulin-like growth factor-1. Diabetologia, 2003, 46, 839-42.

[212] Movafagh, S.; Hobson, J.P.; Spiegel, S.; Kleinman, H.K.; Zukowska, Z. Neuropeptide $\mathrm{Y}$ induces migration, proliferation, and tube formation of endothelial cells bimodally via Y1, Y2, and Y5 receptors. FASEB J., 2006, 20, 1924-6. 